\title{
COMPARATIVE MECHANICAL ANALYSIS BETWEEN EPOXY COMPOSITE REINFORCED WITH CURAUA AND EPOXY COMPOSITE REINFORCED WITH FIBERGLASS*
}

\author{
Natália de Oliveira Roque Maciel $^{1}$ \\ Carolina Gomes Dias Ribeiro ${ }^{2}$ \\ Jordana Barreto Ferreira ${ }^{2}$ \\ Janaina da Silva Vieira ${ }^{2}$ \\ Frederico Muylaert Margem ${ }^{3}$ \\ Carlos Mauríco Fontes Vieira ${ }^{4}$ \\ Sérgio Neves Monteiro ${ }^{5}$
}

\section{Resumo}

Atualmente uma das maiores preocupações da humanidade está relacionada as questões ambientais, o que tem motivado a pesquisa e o desenvolvimento de materiais provenientes de recursos renováveis e ambientalmente amigáveis. A despeito disso, este trabalho objetiva comparar a resistência de compósitos desenvolvidos com fibras naturais e, portanto, ambientalmente amigável e de compósitos desenvolvidos com fibras de vidro, que por sua vez apresentam impactos ambientais desde a fabricação até o descarte. Foram fabricados 13 corpos de provas para amostras contendo $0 \%$ de fibra, $30 \%$ de fibra de curauá e $30 \%$ de fibra de vidro na matriz epoxídica e ensaiado na máquina de tração. Os resultados obtidos apresentam valores bastante superiores para as amostras contendo fibras de vidro, contudo, ao relacionar a tensão do compósito com a respectiva densidade da fibra, foi possível constatar que os compósitos com fibras naturais chegam a apresentar resultados superiores aos compósitos fabricados com fibras de vidro. É possível concluir, portanto, que do ponto de vista da propriedade mecânica em questão é possível substituir as fibras de vidro por fibras de curauá.

Palavras-chave: Compósito; Fibras naturais; Fibra de vidro; Propriedades mecânicas.

\section{COMPARATIVE MECHANICAL ANALYSIS BETWEEN EPOXY COMPOSITE REINFORCED WITH CURAUA AND EPOXY COMPOSITE REINFORCED WITH FIBERGLASS}

\begin{abstract}
Currently, one of the major concerns of humanity is related to environmental issues, which has motivated researches and development of materials from renewable and environmentally friendly resources. Nevertheless, this study aims to compare the resistance of composites developed with natural fibers, therefore environmentally friendly and composites developed with glass fibers, which in turn have environmental impacts from manufacturing to disposal.Thirteen specimens were fabricated to test, what containing $0 \%$ fiber, $30 \%$ curaua fiber and $30 \%$ fiberglass in epoxy matrix and tested in tensile machine. The results show higher values for the samples containing glass fibers, however, to relate the composite tension with its fiber density, it was found that the composites with natural fibers even showed better results than those produced composites with fibers glass. It can be concluded that, from the point of view of mechanical property in question,fiberglass can be replaced by curaua fiber.

Keywords: Composite; Natural fiber; Fiberglass; Mechanical Properties.

1 Graduating in industrial Engineering, Master, Student, LAMAV, State University of the Northern Rio de Janeiro/UENF, Campos dos Goytacazes, Rio de Janeiro, Brazil.

2 Graduating in Metallurgical and Materials Engineering, Student, LAMAV, State University of the Northern Rio de Janeiro/UENF, Campos dos Goytacazes, Rio de Janeiro, Brazil.

3 Doctor in Materials Engineering, Doctor, Assistant teacher, Science center in engineering, Redentor college, Itaperuna, Rio de Janeiro, Brazil.

4 Doctor in Mechanical engineering, Doctor, Professor, Advanced Materials Laboratory, State University of the Northe Fluminense/UENF, Campos dos Goytacazes, Rio de Janeiro, Brazil.

$5 \mathrm{PhD}$ in Materials Engineering, Emeritus Professor, Department of Materials IME, Rio de Janeiro, Brazil.
\end{abstract}




\section{INTRODUCTION}

Modern composite materials, particularly those reinforced with synthetic fibers, such as fiberglass and carbon fiber, has been used since the last century to fulfill the demands required for many technological fields, from home appliances to aerospace parts [1]. However, the energy required to manufacture these fibers generates a large emission of $\mathrm{CO} 2$, which is the factor responsible for global warming. In addition, fiberglass are not recyclable and can not be incinerated, and the waste discarded in landfills, contributing to environmental pollution [2] and currently, the ecological concerns have been highlighted among the claims required by the society in view of its relevance to the quality of life of populations, what has required the companies a new position in their interaction with the environment [3]. Alternatively, studies have been made to replace, where possible, synthetic fibers for natural fibers, since the latter have lower costs, are renewable and biodegradable, its production system does not demand the use of many energy equipment and are energy efficient [4]. Table 1 briefly summarizes the main advantages of using natural fibers in comparison to fiberglass.

Table 1: Comparison between Natural fiber and Glass fiber[2]

\begin{tabular}{lcc}
\hline & Comparison between Natural fiber & and Glass fiber \\
\hline & Natural Fibers & Fiberglass \\
Density & Low & Twicethe natural fiber \\
Cost & low & low, however higher than natural fiber \\
Renewable & Yes & No \\
Recyclable & Yes & No \\
Energy Consumption & Low & High \\
CO $_{2}$ (neutral) & Yes & No \\
AbrasiontoMachines & No & Yes \\
Health RiskWhenlnhaled & No & Yes \\
Degradation & Biodegradable & Nonbiodegradable \\
\hline
\end{tabular}

Ledo [5] states that among the natural fibers with potential applications in composites, curaua stands out as a fiber producer of excellent quality and can be used in the automobile industry since it has good strength, smoothness and low weight.

The Japanese expert JunpeiKanazashi in his research, found that curaua is the fiber that has greater mechanical strength among many others that are cataloged in the global market [6]

The main objective of this study is to investigate the mechanical behavior, specifically the tensile strength of reinforced polymer composites with natural fibers of curaua and polymer composites reinforced with fiberglass (roving) to quantitatively measure the resistance difference between them.

\section{MATERIALS AND METHODS}

\subsection{Curaua Fibers}

The curaua fiber is obtained from a plant with same name, a bromeliad (Ananas Erectifolius), the same pineapple family and was purchased from "Amazon Paper", a 
company that sells natural lignocellulosic fibers grown in the Northern Region of Brazil, specifically in the Amazon. The typical aspect of curaua plant and curaua fiber are shown in Figure 1.

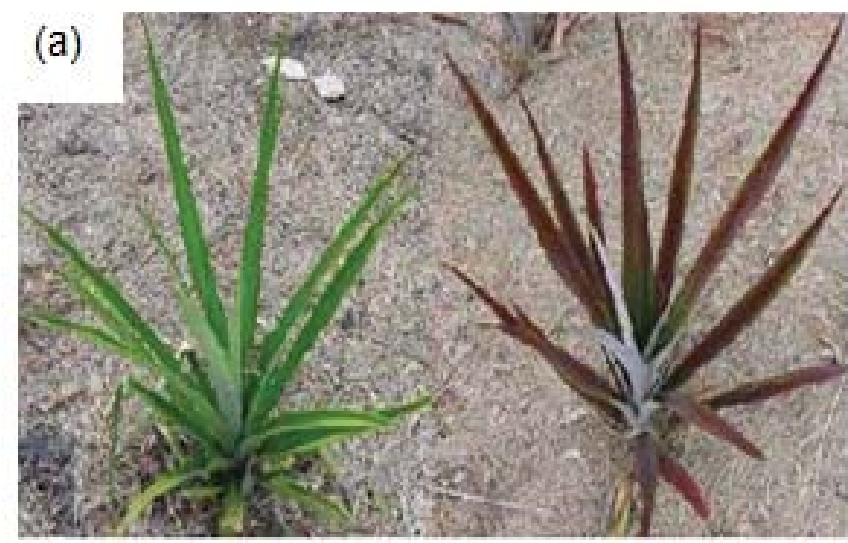

(b)

Figure 1: (a) Curaua Plant and (b) Curaua fiber processed and ready to be used as reinforcement in composite

These fibers were used without any surface treatment, only a fast cleaning and air drying.

Hundred fibers were chosen to measure the length and diameter through a ruler and a profile projector respectively, and with the results obtained were calculated the average length (L) and the average diameter (d). Figure 2 is a histogram measurementswhere it was possible to obtain $L=442 \mathrm{~mm}$ and $\mathrm{d}=$ approximately 0.17 $\mathrm{mm}$ [7]. The fibers were individually weighed and through calculating a geometric cylinder, afforded the density of the fiberglass, which was approximately $0.92 \mathrm{~g} / \mathrm{cm}^{3}$.

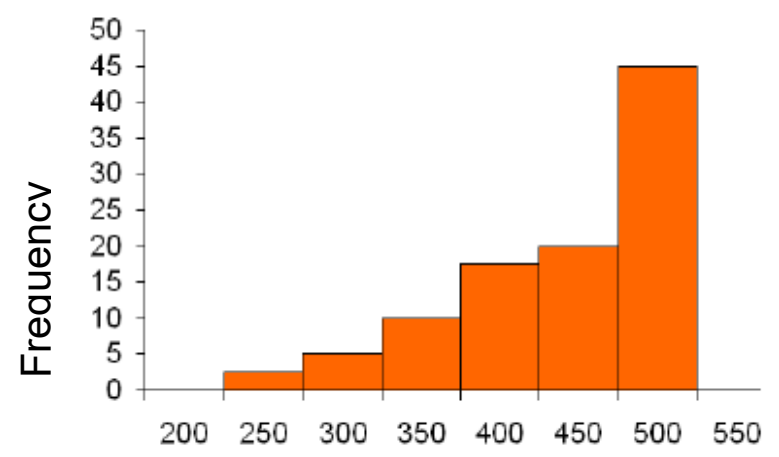

Length $(\mathrm{mm})$

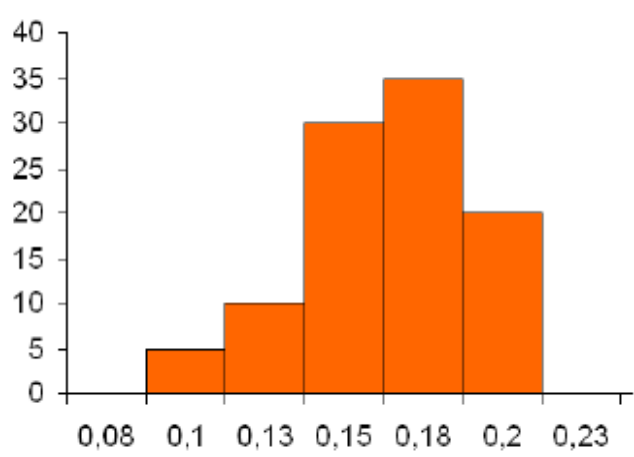

Diameter

Figure 2: Histogram for measures distribution of length and diameter of fiber curaua

\subsection{Fiberglass}

The fiberglasses were purchased from Glass Company. This company provides repairs on vehicles and surfboards using as raw material the fiberglass. According to the manufacturer, the fiberglass is E-type with a density of approximately $2.6 \mathrm{~g} / \mathrm{cm}^{3}$ and a mean diameter in the range from 8 to $14 \mathrm{~mm}$. Figure 2 shows the glass fiber used in this work, the same is in the form of wire, known as roving. 

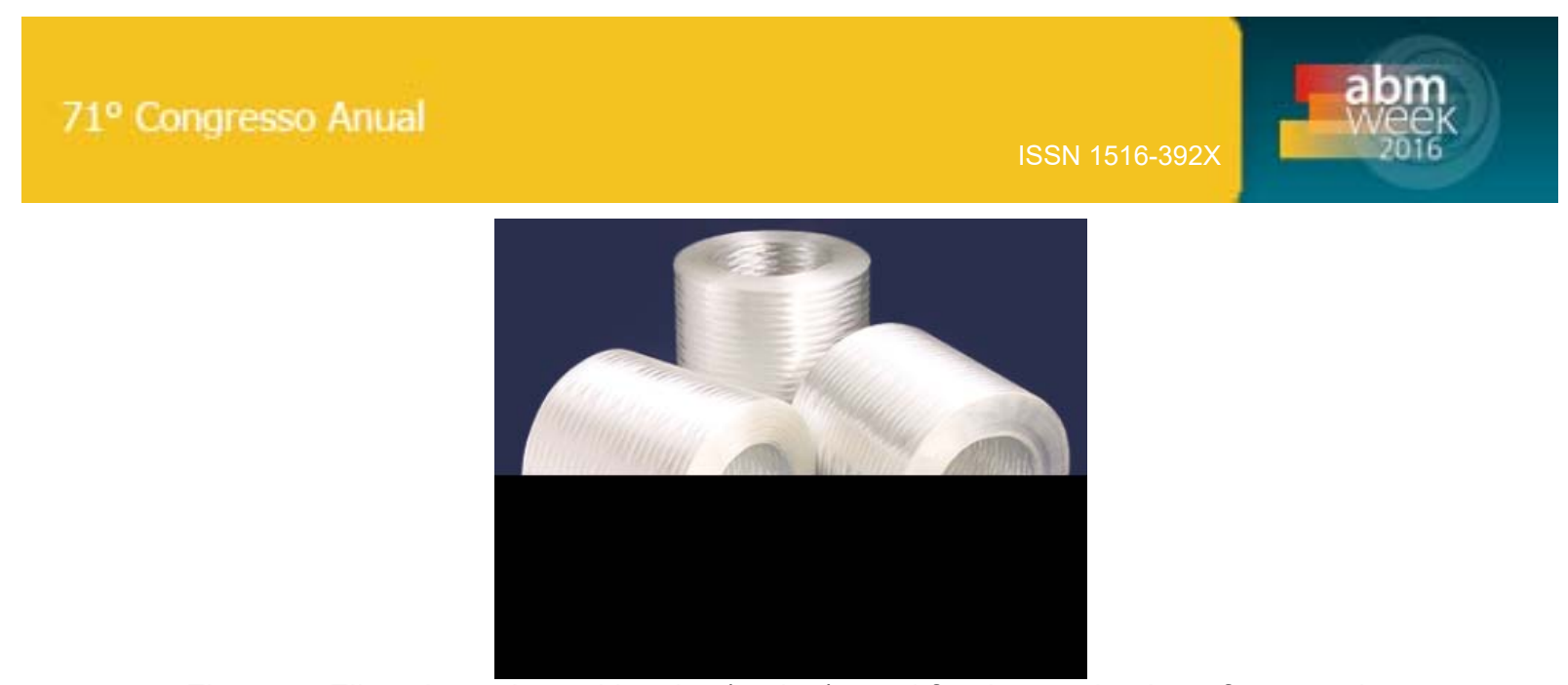

Figure 3: Fiberglass shaped in wire (roving) used for the production of composite

\subsection{Specimens}

To carry out the work were made 13 tensile specimens for each fiber concentration: $0 \%$ fiber, $30 \%$ curaua fiber (CF) and $30 \%$ fiberglass $(F G)$ in polymeric matrix of epoxy. The specimens with $0 \%$ fiber were made in silicone matrix. In the case of the samples with $30 \%$ fiber, the fibers were cut in specimen size, were therefore long and the same were inserted in the metal matrix in alignment and then were bathed in epoxy resin. All specimens were manufactured at room temperature and which were manufactured in the metal matrix were subjected to press to 2.5 tons per 24 hours during the curing process.

After curing, the samples were grinded with the aid of a caliper bodies were measured, numbered and then were subjected to tensile test using INSTRON Model 5582 machine with a speed of $2 \mathrm{~mm} / \mathrm{min}$ at room temperature. Figure 4 shows the steps described above.
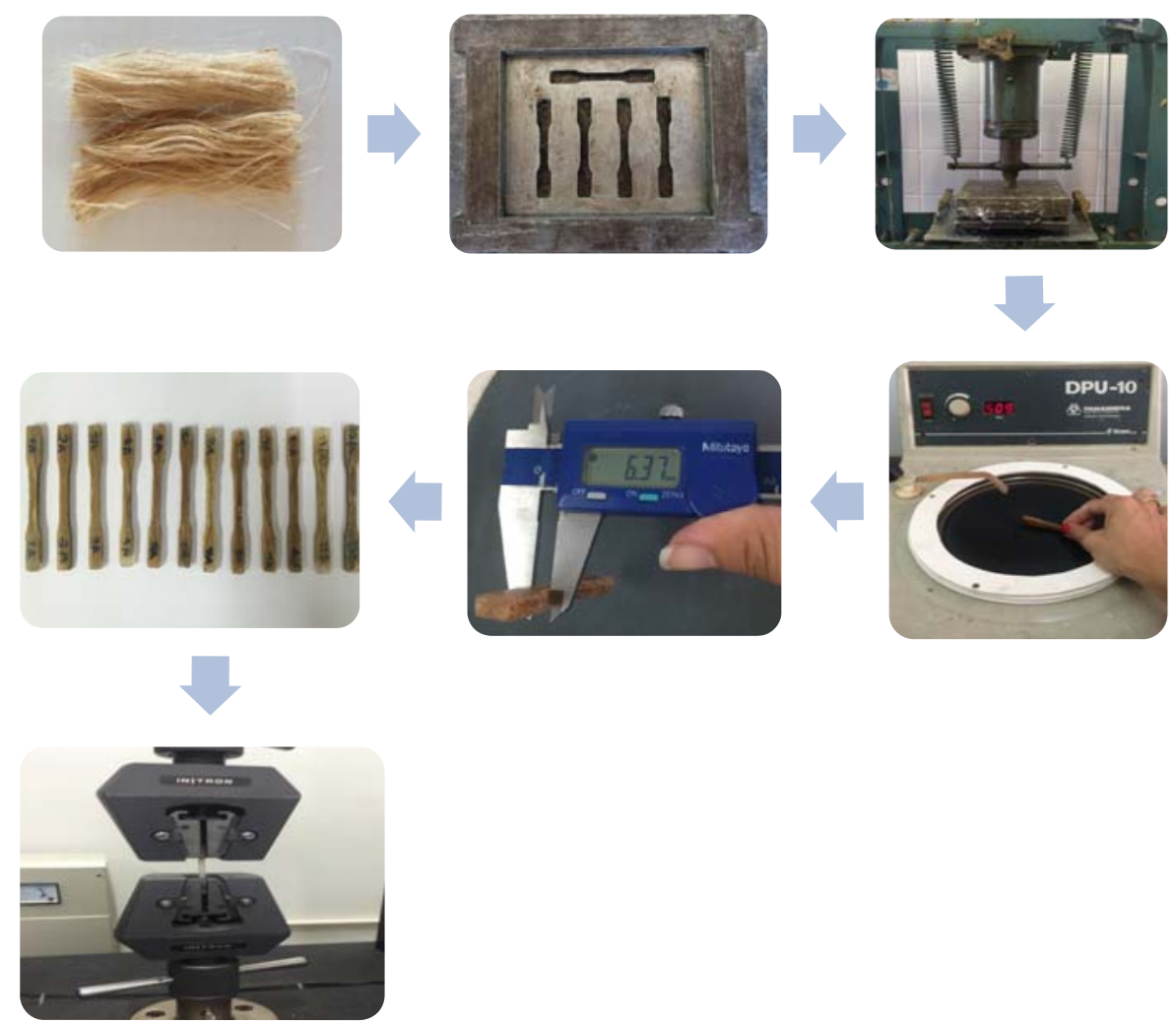

Figure 4: Description of the procedure from manufacturing of specimens $30 \%$ curaua fiber to the tensile test 


\section{RESULTS AND DISCUSSION}

Figure 5 illustrates the macro aspect of tensile ruptured specimens corresponding to the different fibers. In this figure, the fracture of neat epoxy specimens tends to be transversal to the tensile axis; this fact indicates that the fracture mechanism for the pure epoxy matrix was mainly associated with the propagation of transversal cracks. However, with increase of curaua fiber it tends to change the direction of fracture because the fracture follows the fiber and this behavior is associated with a low interface relation between the curaua and the epoxy matrix. The glass fiber specimen did not break.

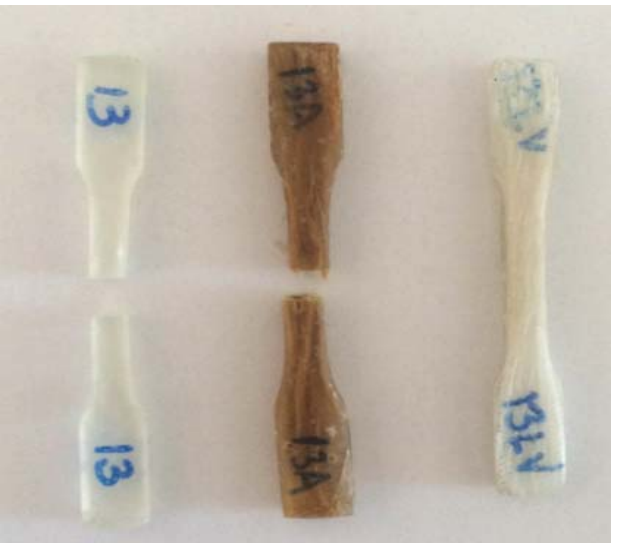

Figure 5: Typical tensile ruptured specimens with $0 \%$ of fiber, $30 \%$ curauá fiber and $30 \%$ glass fiber reinforced epóxi composites

Figure 6 shows a graph of the tensile results obtained by the tensile test for the samples with $0 \%$ fiber, $30 \% \mathrm{FC}$ and $30 \% \mathrm{FG}$ respectively.

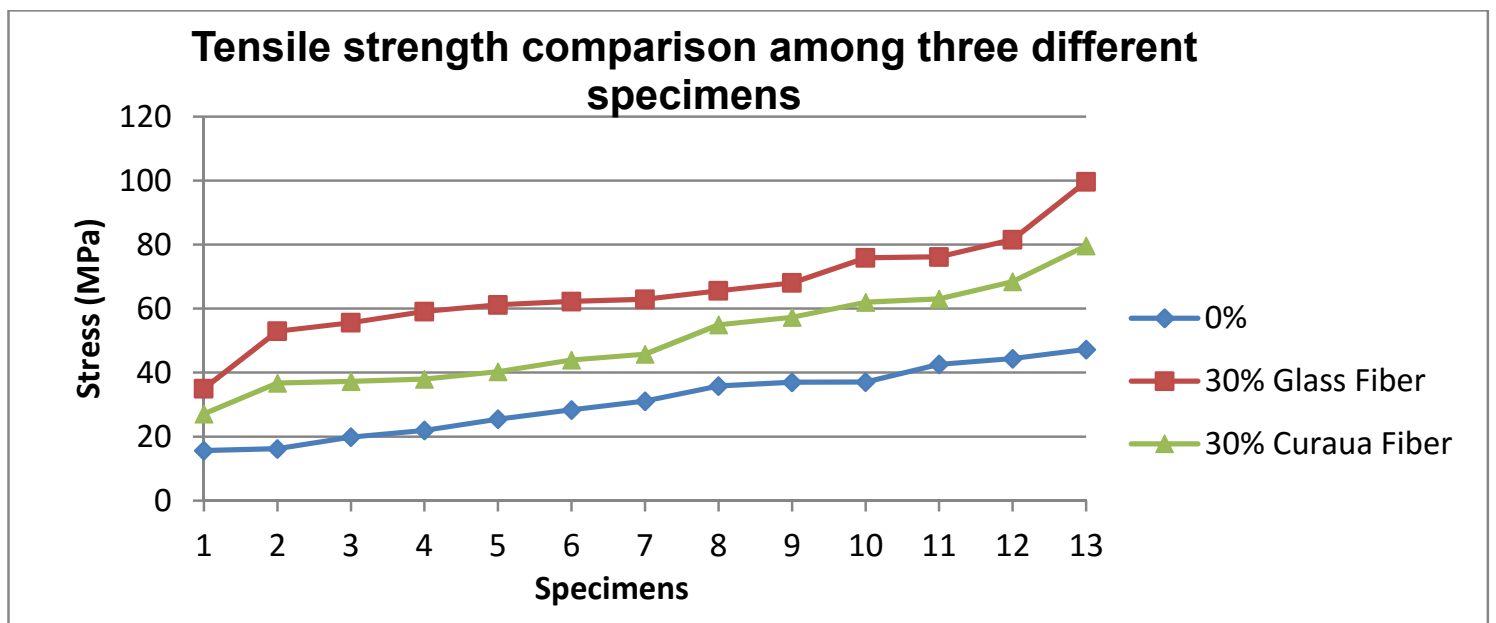

Figure 6: Comparative graph of stress among specimens with $0 \%$ fiber, $30 \%$ CF and $30 \%$ FG

It is possible to realize a significant increase of the tension when fibers are added to resin, or both composites made with $30 \% \mathrm{CF}$ and $30 \% \mathrm{FG}$ had an increased resistance when compared to samples $0 \%$ fiber [8].

The strength obtained from specimens with 30\% FG was greater than the strength obtained with the specimens of CF, however, it was expected, sincethat the natural fibers to be hydrophilic have low compatibility with the matrix that is hydrophobic, resulting in low interfacial adhesion fiber-matrix, directly impacting the results of the mechanical properties [8].Moreover, the mechanical properties and physical properties 
of natural fibers vary considerably depending on the chemical and structural composition and growth conditions, so natural fibers show major irregularities than the fiberglass, cooperating with the lower strength results when compared to homogeneous materials as fiberglass [9]. Although biodegradable materials (green materials) presenting lower properties then synthetic materials properties, its use on an industrial scale is not affected [10].

Because of the materials studied are of different nature and having different properties, it was necessary to evaluate the strength according to the density of each material, thus acquired specific strength values as shown in the graph of Figure 7.

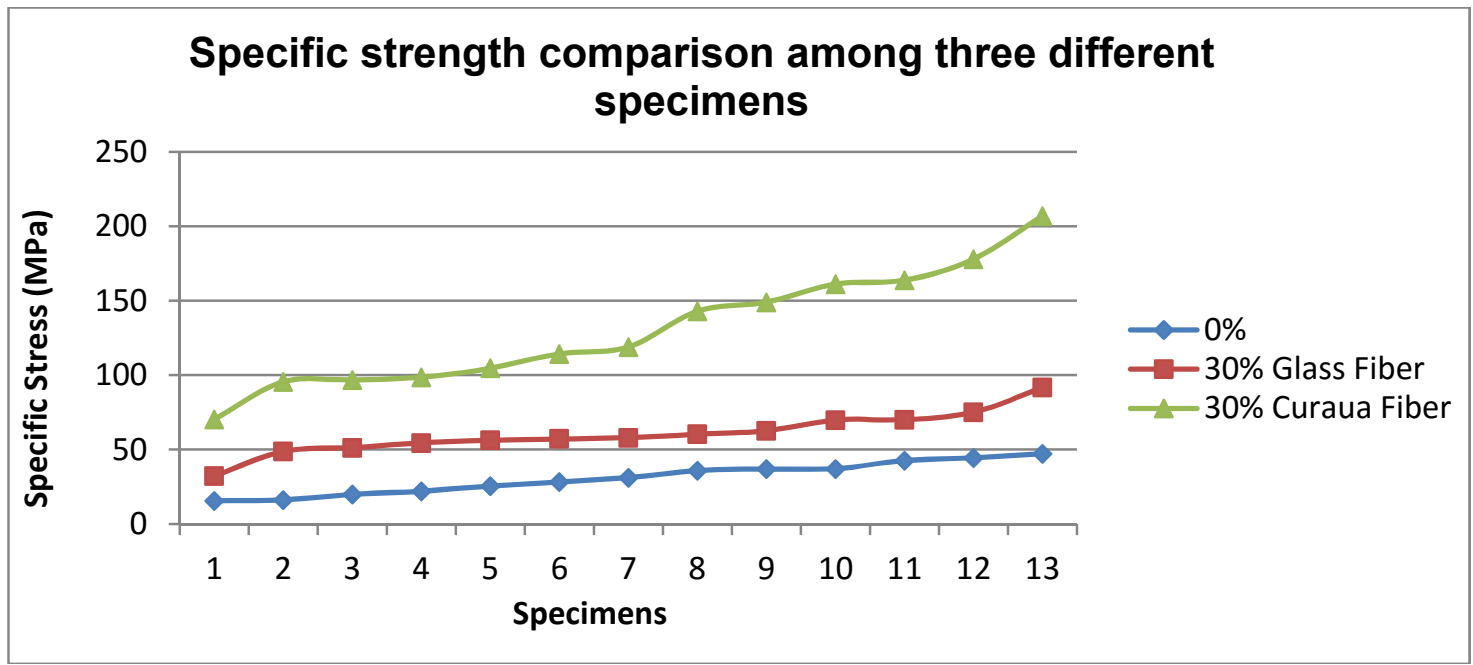

Figure 7: Comparative graph of specific strength obtained among samples with $0 \%$ fiber, $30 \% \mathrm{CF}$ and $30 \%$ FG

By dividing the tensile strength of the material by its density, CF composites become higher than the composite FG, therefore has the best ratio strength / weight or specific strength. Mechanical properties of plant fibers are much lower when compared to those of the most widely used competing with reinforcing fiberglass. However, because of their low density, the specific properties (property-density ratio), strength and stiffness of plant fibers are comparable to the values of fiberglass [2].

It's important to notice that deviations of some of results are significant. It can be explained by the difficult of prepare sample uniformly.

Table 2 shows the average and standard deviation of the samples with $0 \%$ fiber, $30 \%$ CF and $30 \%$ FG.

Tabela 2: Average results and standard deviation of the tensile test for the samples with $0 \%$ fiber, $30 \%$ curaua fiber and $30 \%$ fiberglass.

\begin{tabular}{lccccc}
\hline & $\begin{array}{c}\mathbf{0} \% \\
(\mathbf{M P a})\end{array}$ & $\begin{array}{c}\mathbf{3 0} \% \\
\mathbf{C F} \\
(\mathbf{M P a})\end{array}$ & $\begin{array}{c}\mathbf{3 0 \%} \\
\mathbf{F G} \\
(\mathrm{MPa})\end{array}$ & $\begin{array}{c}\mathbf{3 0 \%} \text { CF Specific } \\
\text { strength (MPa) }\end{array}$ & $\begin{array}{c}\text { 30\% FG Specific } \\
\text { strength (MPa) }\end{array}$ \\
\hline Average & 30.96 & 60.57 & 130.84 & 65.84 & 50.32 \\
\hline
\end{tabular}

By adding curaua fiber in epoxy resin there was an increase of $100 \%$ in strength. For fiberglass, the increase was even more significant, that was, the strength increased $100 \mathrm{MPa}$ compared to the sample without epoxy fiber.

Comparing the results of CF and FGit is realized that the strength has more than doubled, however, to make a more critical analysis, it is evident that CF strength is greater than the FG when taking into account the density of the both materials. 


\section{CONCLUSIONS}

1. The increase amount of fibers have directly influence of the mechanical behavior of composites reinforced with natural fibers. The pure epóxi sample has smaller strength than composite with $30 \%$ of fiber.

2. The results show that at first, the composite with fiberglass is more attractive, however when analyzes the results with the strain/density ratio is possible to conclude that a strength ofcuraua fiber composite is better than fiberglass composite.

\section{Acknowledgements}

The authors thank the support to this investigation by the Brazilian agencies: CNPq, CAPES, FAPERJ and TECNORTE/FENORTE.

\section{REFERENCES}

1. Chawla KK. Composite Materials Science and Engineering. 2nd edition. New York: Springer-Verlag; 1998.

2. Wambua P, Ivens I, Verpoest I. "Natural fibers: can they replace glass and fibre reinforced plastics?". Composites Science and Technology. 2003; 63: 1259-1264.

3. Donaire D. Considerações sobre a influência da variável ambiental na empresa. Revista de Administração de Empresas. 1994; 34(2): 68-77.

4. Monteiro SN, Lopes FPD, Ferreira AS, Nascimento DCO. Naturalf iber polymer matrix composites: Cheaper, tougher, and environmentally friendly. JOM. 2009; 61(1):17-22.

5. Ledo IAM. O cultivo no Lago Grande da França. $1^{\circ}$ edição. Belém: Banco de Crédito da Amazônia S/A; 1964.

6. Takahashi R, Pereira LCO, Oliveira DRC, Fujiyama RT. Fabricação de mantas de fibra de sisal e de curauá. COBENGE. 2011 [acesso em 24 Fev. 2014]. Disponível em: http://www.abenge.org.br/CobengeAnteriores/2011/sessoestec/art1765.pdf.

7. Monteiro SN, Aquino RCMP, Lopes FPD, Carvalho EA de, d' Almeida JRM. Mechanical behavior and structural characteristics of polymeric composites reinforced with continuous and aligned curaua fibers. Matéria. 2006;11(3):197-203.

8. Salit MS. Tropical Natural Fibre Composites: Properties, Manufacture and Applications. Malaysia: Springer; 2014.

9. Mohanty AK, Misra M, Drzal LT. Natural Fibers, Biopolymers, and Biocomposites. Flórida: CRC Press; 2005.

10. ANAIS - VIII Congresso Nacional de Engenharia Mecânica 2001 [Internet]. [citado 11 de abril de 2016]. Recuperado de:

http://www.abcm.org.br/anais/creem/2001/anais/a06_05.html 